\title{
Dopamine $D_{1}$ vs $D_{5}$ receptor-dependent induction of seizures in relation to DARPP-32, ERK1/2 and GluR1-AMPA signalling
}

\author{
Gerard J. O'Sullivan ${ }^{\mathrm{a}}$, Mark Dunleavy ${ }^{\mathrm{b}}$, Kerstin Hakansson ${ }^{\mathrm{a}, \mathrm{c}}$, Mario Clementi ${ }^{\mathrm{c}}$, Anthony \\ Kinsella $^{a}$, David T. Croke ${ }^{a}$, John Drago ${ }^{d}$, Allen A. Fienberg ${ }^{e}$, Paul Greengard ${ }^{f}$, David R. \\ Sibley $^{\mathrm{g}}$, Gilberto Fisone ${ }^{\mathrm{c}}$, David C. Henshall ${ }^{\mathrm{b}}$, and John L. Waddington ${ }^{\mathrm{a},{ }^{,}}$
}

aMolecular \& Cellular Therapeutics and RCSI Research Institute, Royal College of Surgeons in Ireland, Dublin 2, Ireland bepartment of Physiology and Medical Physics, Royal College of Surgeons in Ireland, Dublin 2, Ireland 'Department of Neuroscience, Karolinska Institutet, Stockholm, Sweden dHoward Florey Institute, The University of Melbourne, Victoria 3010,


Cellular Neuroscience, The Rockefeller University, New York 10021, USA 9Molecular Neuropharmacology Section, National Institute of Neurological Disorders and Stroke, National Institutes of Health, Bethesda, Maryland 20892, USA

\section{Summary}

\begin{abstract}
Recent reports have shown that the selective dopamine $\mathrm{D}_{1}$-like agonist SKF 83822 [which stimulates adenylate cyclase, but not phospholipase $\mathrm{C}$ ] induces prominent behavioral seizures in mice, whereas its benzazepine congener SKF 83959 [which stimulates phospholipase C, but not adenylate cyclase] does not. To investigate the relative involvement of $D_{1} v_{s} D_{5}$ receptors in mediating seizures, ethological behavioral topography and cortical EEGs were recorded in $\mathrm{D}_{1}, \mathrm{D}_{5}$ and DARPP-32 knockout mice in response to a convulsant dose of SKF 83822. SKF 83822induced behavioral and EEG seizures were gene dose-dependently abolished in $\mathrm{D}_{1}$ knockouts. In both heterozygous and homozygous $\mathrm{D}_{5}$ knockouts, the latency to first seizure was significantly increased and total EEG seizures were reduced relative to wild-types. The majority (60\%) of homozygous DARPP-32 knockouts did not have seizures; of those having seizures (40\%), the latency to first seizure was significantly increased and the number of high amplitude, high frequency polyspike EEG events was reduced. In addition, immunoblotting was performed to investigate downstream intracellular signalling mechanisms at $\mathrm{D}_{1}$-like receptors following challenge with SKF 83822 and SKF 83959. In wild-types administered SKF 83822, levels of ERK1/2 and GluR1 AMPA receptor phosphorylation increased two-fold in both the striatum and hippocampus; in striatal slices DARPP-32 phosphorylation at Thr34 increased five-fold relative to vehicle-treated controls. These findings indicate that $\mathrm{D}_{1}$, and to a lesser extent $\mathrm{D}_{5}$, receptor coupling to DARPP-32, ERK1/2 and glutamatergic signalling is involved in mediating the convulsant effects of SKF 83822.
\end{abstract}

\footnotetext{
(C) 2008 Elsevier Ltd. All rights reserved.

"Corresponding author: Dr. John L. Waddington, Molecular \& Cellular Therapeutics, Royal College of Surgeons in Ireland, St. Stephen's Green, Dublin 2, Ireland. Tel: +353-1-4022420; Fax: +353-1-4022453; jwadding@ @rsi.ie.

Publisher's Disclaimer: This is a PDF file of an unedited manuscript that has been accepted for publication. As a service to our customers we are providing this early version of the manuscript. The manuscript will undergo copyediting, typesetting, and review of the resulting proof before it is published in its final citable form. Please note that during the production process errors may be discovered which could affect the content, and all legal disclaimers that apply to the journal pertain.
} 


\section{Keywords}

Dopamine $\mathrm{D}_{1}$-like receptors; Seizures; Adenylate cyclase; DARPP-32; ERK1/2; Knockout

\section{Introduction}

Classical pharmacological approaches and, more recently, studies in gene knockout mice have shown that stimulation of dopamine $\mathrm{D}_{1}$-like $\left(\mathrm{D}_{1}\right.$ and $\left.\mathrm{D}_{5}\right)$ and $\mathrm{D}_{2}$-like $\left(\mathrm{D}_{2 \mathrm{~L} / \mathrm{S}}, \mathrm{D}_{3}\right.$ and $\mathrm{D}_{4}$ ) receptors can lower and elevate seizure threshold, respectively (Starr, 1996;

Weinshenker and Szot, 2002). Interestingly, the ability of selective D1-like agonists to induce seizures (DeNinno et al., 1991; Holmes et al., 2001) appears to be critically dependent on their intracellular signal transduction coupling. Specifically, the selective D1like agonist SKF 83822, which stimulates adenylate cyclase (AC), but not phospholipase C (PLC)-mediated phosphoinositide hydrolysis (Undie et al., 1994; Peacock and Gerlach, 2001; Rashid et al., 2007), induces prominent behavioral seizures in mice (O'Sullivan et al., 2004), whereas its benzazepine congener SKF 83959, which stimulates PLC, but not AC (Panchalingam and Undie, 2001; Jin et al., 2003; Rashid et al., 2007), does not. Furthermore, induction of behavioral seizures following challenge with SKF 83822 is conserved in congenic $\mathrm{D}_{5}$ knockout mice, indicating that among $\mathrm{D}_{1}$-like receptors, selective $\mathrm{D}_{1}$ receptor coupling to $\mathrm{AC}$ may be important in seizure susceptibility (O'Sullivan et al., 2005).

In recent years, it has become apparent that downstream signalling at $\mathrm{AC}$-linked $\mathrm{D}_{1}$-like receptors is more complex than previously envisaged. Dopamine and cAMP-regulated phosphoprotein, $\mathrm{Mw} 32 \mathrm{kDa}$ (DARPP-32) is a signal integration molecule that functions as a potent inhibitor of protein phosphatase 1 (PP1) when phosphorylated at Thr34 by protein kinase A (PKA) and an inhibitor of PKA when phosphorylated at Thr75 by cyclindependent kinase 5 (Svenningsson et al., 2004). In addition, it has now been established that DARPP-32-mediated inhibition of PP1 can also activate extracellular-regulated kinases 1 and 2 (ERK1/2; Valjent et al., 2000, 2005; Girault et al., 2007). ERK1/2 are members of the mitogen activated protein kinase (MAPK) family and are known to be involved in diverse biological processes, including synaptic plasticity and epileptogenesis (Merlo et al., 2004; Thomas and Huganir, 2004). Evidence for $\mathrm{D}_{1}$-like receptor linkage to MAPK signalling has recently emerged with the finding that dopamine-induced cytotoxicity involves $\mathrm{D}_{1}$ receptormediated ERK1/2 activation (Chen et al., 2004).

A functional role for dopamine in seizure generation has traditionally received little attention, with the majority of research focused on glutamatergic and GABAergic mechanisms. However, recent findings that (a) phosphorylation of the AMPA receptor subunit GluR1 at Serine 845 is increased in response to DARPP-32-mediated inhibition of PP1 (Snyder et al., 2000) and (b) AMPA receptor cell surface expression is up-regulated following $\mathrm{D}_{1}$ receptor activation in a PKA-dependent manner (Mangiavacchi and Wolf, 2004) demonstrate that dopamine can potentiate excitatory glutamatergic transmission.

To elaborate the importance of selective AC stimulation in mediating subsets of $\mathrm{D}_{1}$-like dependent behavior, including seizures, we report the first ethological assessment of SKF 83822 in $\mathrm{D}_{1}$ knockout mice. Furthermore, to investigate the potential involvement of DARPP-32 in mediating seizure induction by AC-linked $\mathrm{D}_{1}$-like receptors, the electroencephalogram (EEG) profile of SKF 83822 was examined in dopamine $\mathrm{D}_{1}, \mathrm{D}_{5}$ and DARPP-32 mutants. Finally, immunoblotting has been employed to identify possible roles for ERK1/2 activation and functional dopamine-glutamate interactions in these processes. 


\section{Materials and methods}

\subsection{Mutant mice}

For behavioral and EEG studies, the original F2 hybrid $(129 \times \mathrm{C} 57 \mathrm{BL} / 6)$ strain containing the mutated $D_{1}$ receptor, $D_{5}$ receptor and DARPP-32 alleles were generated as reported previously (Drago et al., 1994; Fienberg et al., 1998; Hollon et al., 2002). To establish congenic lines, heterozygous knockouts of these hybrid $\mathrm{D}_{1}, \mathrm{D}_{5}$ and DARPP-32 strains were backcrossed to wild-type C57BL/6 for 15, 10 and 11 generations, respectively (McNamara et al., 2003; Nally et al., 2004; O'Sullivan et al., 2005). Analysis of isolated genomic DNA by PCR was used to genotype the progeny of heterozygous $\mathrm{D}_{1}$, heterozygous $\mathrm{D}_{5}$ and homozygous DARPP-32 intermatings. For each knockout line, wild-type, heterozygous and homozygous knockout littermates of the same generational age from these intermatings were used. For biochemical studies, adult male C57BL/6 mice (Charles River, Sulzfeld, Germany) weighing $25-30 \mathrm{~g}$ were used. Mice were housed in groups of five, with standard laboratory chow and water available ad libitum, and were maintained at $21 \pm 1^{\circ} \mathrm{C}$ on a $12 \mathrm{~h} /$ $12 \mathrm{~h}$ (08:00 on; 20:00 off) light/dark schedule. All efforts were made to minimize the number of animals used and their suffering. These studies were approved by the Research Ethics Committee of the Royal College of Surgeons in Ireland and the Swedish Animal Welfare Agency and were conducted under license from the Department of Health \& Children in accordance with Irish legislation and European Communities Council Directive 86/609/EEC for the care and use of experimental animals.

\subsection{Behavioral assessment}

For evaluation of the SKF 83822-induced ethogram, female homozygous $\mathrm{D}_{1}$ knockout and wild-type mice were removed from their home cage and placed individually in clear glass observation cages $(36 \times 20 \times 20 \mathrm{~cm})$ with wood shavings as bedding material. Mice were then allowed to habituate for a period of $3 \mathrm{~h}$ to reduce initially high levels of activity in order to optimise detection of agonist-induced stimulatory effects. Immediately following challenge with SKF $83822(0.016-2.0 \mathrm{mg} / \mathrm{kg}$ s.c.) or vehicle, assessments were carried out using a rapid time-sampling behavioral checklist technique and stereotypy rating scale, as previously described (Nally et al., 2004; c, 2006; O'Tuathaigh et al., 2006). For this study, the following components of the ethogram are reported: sniffing (flaring of nostrils with movement of vibrissae); locomotion (coordinated movement of all four limbs producing a change in location); rearing to wall (front paws reaching upwards onto or towards a cage wall while standing on hind limbs); total grooming (grooming of any form); intense grooming (characteristic, programmed syntax of sequential grooming of the snout and then the face with the forepaws, followed by grooming of the hind flank/anogenital region with the snout); seizures, characterised as any of the following phases occurring within the 60 min observation period: phase $1=$ sustained immobility/rigidity; phase $2=$ rearing with forepaw myoclonus; phase $3=$ generalized clonus; phase $4=$ tonic-clonic seizure or rapid jumping and wild running (Ferraro et al., 1999; McKhann et al., 2003; O'Sullivan et al., 2006); stillness (motionless: awake with no behavior evident, or asleep). Under these conditions mice were used on two occasions only, separated by a drug-free interval of at least one week; on each occasion mice were allocated randomly to one of the various treatment groups. All assessments were made by an observer who was unaware of genotype and treatment for each animal.

\subsection{Electroencephalographic recording}

Seizure studies were carried out in a manner similar to that described previously (Shinoda et al., 2004). Briefly, for surgical implantation of extradural recording electrodes, adult male D1, D5 or DARPP-32 knockouts or wild-types were initially anaesthetised using 5\% isoflurane (Abbott Laboratories, Kent, $\mathrm{UK}$ ) in $\mathrm{O}_{2}$, placed in a stereotaxic frame and 
maintained under anaesthesia using $1.5 \%$ isoflurane in $\mathrm{O}_{2}$. Temperature was maintained normothermic $\left(37 \pm 0.5^{\circ} \mathrm{C}\right)$ by means of a rectal thermometer and thermostatically controlled heating pad (Harvard Apparatus, MA, USA). The scalp was incised and a burr hole drilled in the exposed cranium over each hippocampus and the frontal cortex. Bitemporal recording electrodes and a frontal reference electrode (Plastics One Inc., VA, USA) were then affixed to the skull using dental cement (Kemdent, Wiltshire, UK). Following surgery, animals were placed in an incubator (Harvard Apparatus, MA, USA) to recover from anaesthesia before being returned to their homecage. $24-48 \mathrm{~h}$ post-surgery, experimental animals were connected to a digital EEG monitoring apparatus (AS40 amplifier system; Grass Technologies, RI, USA) and a 30 min baseline EEG was recorded before administration of SKF 83822 (2.0 mg/kg s.c.) or vehicle. EEGs were recorded for $1 \mathrm{~h}$ post-injection and subsequently analysed by a trained observer unaware of genotype or treatment for each animal; to ensure delayed seizure events were not present, a $5 \mathrm{~h}$ EEG was recorded following administration of SKF 83822 for each mutant line on at least one occasion. EEG patterns were classified as previously described (Shinoda et al., 2004): type I = baseline recording; type II = high frequency $(>1 \mathrm{~Hz}$ ), low voltage spiking (no behavioral correlate); type III = low frequency $(<1 \mathrm{~Hz}$ ), high voltage spiking (corresponding to a phase $2 / 3$ behavioral seizure above); type IV = high frequency, high voltage spiking (corresponding to a phase 4 behavioral seizure above).

\subsection{Tissue extraction procedures}

For phosphoprotein determination in whole brain structures, male C57BL/6 mice were sacrificed by decapitation at specific time points $(15,30$ or $60 \mathrm{~min})$ following challenge with SKF $83822(2.0 \mathrm{mg} / \mathrm{kg}$ s.c. $)$ or vehicle and heads immediately immersed in liquid nitrogen for $6 \mathrm{~s}$. The brains were then removed, and the striatum and hippocampus rapidly dissected on an ice-cold surface, sonicated in $1 \%$ sodium dodecyl sulfate and boiled for $10 \mathrm{~min}$. This procedure prevents protein phosphorylation and dephosphorylation which occur very rapidly post-mortem (Svenningsson et al., 2000). For preparation and incubation of striatal slices, male C57BL/6 mice were decapitated and the brains rapidly dissected out on an ice-cold surface and cut in $250 \mu \mathrm{m}$ coronal slices using a Leica VT1000S vibrating blade microtome (Leica Microsystems AB, Kista, Sweden). Dorsal striata were dissected out from each slice under a microscope. Two striatal coronal slices were randomly placed in individual $5 \mathrm{ml}$ polypropylene tubes containing $2 \mathrm{ml}$ of Krebs-Ringer biocarbonate buffer (KRB in $\mathrm{mM}$ : $\mathrm{NaCl} 118, \mathrm{KCl} 4.7, \mathrm{CaCl}_{2}$ 1.3, $\mathrm{MgSO}_{4} 1.5, \mathrm{KH}_{2} \mathrm{PO}_{4} 1.2, \mathrm{NaHCO}_{3} 25$ and glucose 11.7; equilibrated with $95 \% \mathrm{O}_{2}, 5 \% \mathrm{CO}_{2}[\mathrm{v} / \mathrm{v}], \mathrm{pH} 7.3$ ). The samples were incubated at $30^{\circ} \mathrm{C}$ for two 30 min periods, each followed by replacement with $2 \mathrm{ml}$ fresh KRB buffer. Samples were then incubated with either SKF $83822(1 \mu \mathrm{M})$ or vehicle for $5 \mathrm{~min}$. The reaction was rapidly terminated by removing the medium, sonicating the slices in $1 \%$ sodium dodecyl sulfate and boiling for $10 \mathrm{~min}$.

\subsection{Determination of phosphoproteins}

Determination of protein phosphorylation was carried out in a manner similar to that described previously (Hakansson et al., 2006). Briefly, aliquots (5 $\mu \mathrm{l}$ ) of the homogenate were used for protein determination using the bicinchoninic acid method (Pierce, Oud Beijerland, Netherlands). Equal amounts of protein $(30 \mu \mathrm{g})$ from each sample were loaded onto $10 \%$ polyacrylamide gels. Proteins were separated by sodium dodecyl sulfate polyacrylamide gel electrophoresis and transferred to either Immobilon-FL transfer membranes (Millipore, MA, USA) or polyvinylidine diflouride membranes (Amersham Pharmacia Biotech, Uppsala, Sweden), as previously described (Towbin et al., 1979). Membranes were then immunoblotted using affinity-purified polyclonal antibodies that selectively detect phospho-Ser845-GluR1 (Upstate, NY, USA) or phospho-Thr183/Tyr185ERK1/2 (Cell Signalling Technology, MA, USA), or a monoclonal antibody against 
phospho-Thr34-DARPP-32 (Snyder et al., 1992). Antibodies against GluR1 (Upstate, NY, USA), ERK1/2 (Cell Signalling Technology, MA, USA) and DARPP-32 (Hemmmings and Greengard, 1986) that are not phosphorylation state-specific were used to estimate the total amount of proteins. Antibody binding was revealed by either one of the following two techniques. In experiments where the ECL immunoblotting detection method was employed, a goat anti-mouse horseradish peroxidase-linked IgG (Pierce, Oud Beijerland, Netherlands) was used as a secondary antibody and the resulting chemiluminescent signal was detected by autoradiography. Quantification of the bands corresponding to the phosphorylated or nonphosphorylated proteins was by densitometry using NIH Image software (version 1.63). Alternatively, detection was performed using fluorescent secondary antibodies (Molecular probes, OR, USA and Rockland Immunochemicals, PA, USA). On these occasions, quantification of antibody binding was by fluorimetry using a Li-Cor Odyssey infrared fluorescent detection system (Li-Cor, NE, USA).

\subsection{Drugs}

The following drugs were used: SKF 83822 [6-chloro-2,3,4,5-tetrahydro-1-(3methylphenyl)-3-(2-propenyl)-1H-3-benzazepine-7,8-diol hydrobromide; Tocris Bioscience, Bristol, UK]; SKF 83959 [3-methyl-6-chloro-7,8-dihydroxy-1-(3-methylphenyl)-2,3,4,5tetrahydro-1H-3-benzazepine; RBI/SRI/NIMH Chemical Synthesis Program, USA]. SKF 83822 was dissolved in $0.5 \%$ dimethyl sulfoxide and administered subcutaneously into the flank in a volume of $4.0 \mathrm{ml} / \mathrm{kg}$; control mice received $0.5 \%$ dimethyl sulfoxide alone administered in an identical manner. SKF 83959 was dissolved in distilled water and administered subcutaneously into the flank in a volume of $2.0 \mathrm{ml} / \mathrm{kg}$; control mice received distilled water alone in an identical manner.

\subsection{Data analysis}

As described previously (Nally et al., 2004; O'Sullivan et al., 2004, 2006; O'Tuathaigh et al., 2006), for specification of the agonist-induced ethogram, the total 'counts' for each individual behavior were determined as the number of $5 \mathrm{~s}$ observation windows in which a given behavior was evident, summed over the $3 \times 15 \min [0-15,20-35,40-55]$ cycle periods; data were expressed as means \pm SEM. Stereotypy scores were averaged over the 60 min period and expressed similarly. 'Counts' for individual behaviors in relation to agonist dose were analysed using ANOVA after square-root transformation followed by Student's ttest; stereotypy scores were analysed using the Kruskal-Wallis nonparametric ANOVA followed by Mann-Whitney U-test. For determination of protein phosphorylation in whole striatum/hippocampus and striatal slices, densitometry values were analysed using ANOVA followed by Dunnett's test and Student's t-test, respectively.

\section{Results}

\subsection{Ethological response to SKF 83822 in $D_{1}$ knockouts}

On examining 11 female homozygous congenic $\mathrm{D}_{1}$ knockout mice, mean body weight $(19 \pm 1 \mathrm{~g}$, mean age $184 \pm 11$ days) was reduced $(-20 \%, p<0.001)$ relative to 15 female wildtype controls $(23 \pm 1 \mathrm{~g}$, mean age $187 \pm 8$ days). Challenge with SKF $83822(0.016-2.0 \mathrm{mg} /$ $\mathrm{kg}$ ) induced prominent behavioral seizures at higher doses in wild-type mice [effect of dose, $F(4,37)=15.77, p<0.001]$, whereas $\mathrm{D}_{1}$ knockouts did not have behavioral seizures at any dose [effect of genotype, $F(1,37)=45.81, p<0.001$; dose $\times$ genotype interaction, $F(4,37)=$ 15.77, $p<0.001$ ] (Fig. 1). Co-stimulation of sniffing [effect of dose, $F(4,37)=3.46, p<$ 0.05 ] and locomotion [effect of dose, $F(4,37)=5.94, p<0.001$ ] in wild-type mice was not observed in $\mathrm{D}_{1}$ knockout mice [effects of genotype, $F(1,37)=31.77, p<0.001$ and $F(1,37)$ $=60.81, p<0.001$, respectively]. Among topographies of rearing behavior, a significant increase in rearing to wall in wild-types [effect of dose, $F(4,37)=3.00, p<0.05$ ] was not 
observed in $\mathrm{D}_{1}$ knockouts [effect of genotype, $F(1,37)=34.67, p<0.001$ ]. While SKF 83822 did not induce general or syntactic (intense) grooming in wild-types, levels of grooming were elevated in $\mathrm{D}_{1}$ knockouts at higher doses [effect of genotype, $F(1,37)=$ $18.45, p<0.001$; dose $\times$ genotype interaction, $F(4,37)=2.89, p<0.05]$. A dose-dependent abolition of stillness in wild-types [effect of dose, $F(4,37)=4.50, p<0.01$ ] was not observed in $\mathrm{D}_{1}$ knockouts [effect of genotype, $F(1,37)=22.45, p<0.001$ ]. The emergence of mild stereotyped behavior in wild-types at higher doses of SKF 83822 was not observed in $\mathrm{D}_{1}$ knockouts. A comparable ethological responsive to SKF 83822 reported here in female wild-types has previously been described in males (O'Sullivan et al., 2004).

\subsection{SKF 83822-induced EEG profile in $D_{1}, D_{5}$ and DARPP-32 knockouts}

Latency to first seizure, total number of seizures over $60 \mathrm{~min}$ and the number of type IV seizures following systemic administration of SKF $83822(2.0 \mathrm{mg} / \mathrm{kg})$ in congenic $\mathrm{D}_{1}, \mathrm{D}_{5}$ and DARPP-32 knockouts are shown in Table 1. Vehicle-treated wild-type or knockout mice did not have seizures at any point (data not shown). In wild-type mice for the three knockout lines, challenge with SKF 83822 induced polyspike paroxysmal seizure EEG with a mean seizure latency of $19 \mathrm{~min}$; there was a mean of 8 seizures over the 60 min period, of which approximately $75 \%$ were type IV EEG seizure events. SKF 83822-induced seizures were gene dose-dependently and completely abolished in $\mathrm{D}_{1}$ knockouts $(p<0.01)$ (Fig. 2 , Table 1). In both heterozygous and homozygous $\mathrm{D}_{5}$ knockouts, latency to first seizure was significantly increased $(+59 \%, p<0.01)$, with significant reductions in the overall number of seizures $(-75 \%, p<0.01)$ and type IV events $(-87 \%, p<0.05)$ in homozygous $\mathrm{D}_{5}$ knockouts relative to wild-types. The majority (60\%) of homozygous DARPP-32 knockouts did not have seizures; of those evidencing seizures (40\%), latency to first seizure was significantly increased $(+61 \%, p<0.01)$, while the overall number of seizures and type IV events were reduced $(-80 \%, p<0.05$ and $-75 \%, p<0.05$ respectively) relative to wildtypes.

\subsection{SKF 83822- and SKF 83959-induced protein phosphorylation in the striatum and hippocampus}

At $15 \mathrm{~min}$ post administration of SKF $83822(2.0 \mathrm{mg} / \mathrm{kg}$ s.c.), levels of ERK1/2 phosphorylation increased 2.5-fold in both the striatum [ERK1, $F(3,42)=7.2, p<0.001$; ERK2, $F(3,42)=6.1, p<0.01]$ and hippocampus [ERK1, $F(3,41)=8.9, p<0.001$; ERK2, $F(3,41)=9.1, p<0.001]$ and remained significantly elevated throughout the $60 \mathrm{~min}$ assessment period (Fig. 3a,b). In contrast, systemic administration of PLC-stimulating SKF $83959(2.0 \mathrm{mg} / \mathrm{kg})$ had no effect on ERK1/2 phosphorylation in the striatum (Fig. 3c); however, a minor but significant increase in ERK1/2 phosphorylation following challenge with SKF 83959 was detected in the hippocampus at 15 and $60 \mathrm{~min}$ [ERK1, $F(3,21)=5.6, p$ $<0.01$; ERK2, $F(3,21)=4.2, p<0.05$ ] (Fig. 3d). SKF 83822 also induced prominent GluR1 AMPA receptor phosphorylation at Ser845 in both the striatum $[F(3,42)=32.3, p<0.001]$ and hippocampus $[F(3,42)=27.7, p<0.001]$ after $15 \mathrm{~min}$ and this effect was maintained at subsequent time points (Fig. 4a,b). In contrast, PLC-stimulating SKF 83959 induced only modest Ser845 GluR1 phosphorylation in the striatum at later time points $[F(3,21)=4.6, p<$ 0.05] and was without effect on basal levels of Ser845 GluR1 phosphorylation in the hippocampus (Fig 4C, D). Phosphorylation of DARPP-32 at Thr34 in response to SKF 83822 was more complex: the scatter plot in Fig. 5 b shows up to a two-fold increase in some animals yet up to a two-fold decrease in others, resulting in no overall effect of SKF 83822 on mean DARPP-32 phosphorylation in the striatum at any time point (Fig. 5a); rather, variance in SKF 83822-induced DARPP-32 phosphorylation markedly exceeded that in vehicle-treated controls at 15,30 and $60 \mathrm{~min}[F(10,11)=9.9, F(11,11)=10.1$ and $F(11,11)$ $=8.9$, respectively, each $p<0.001]$. However, in striatal slices, a five-fold increase in DARPP-32 phosphorylation at Thr34 was recorded 5 min post-SKF 83822 administration 
relative to vehicle-treated controls $(p<0.001)$ (Fig. 5c). In contrast, administration of PLCstimulating SKF 83959 reduced levels of DARPP-32 phosphorylation at Thr34 in the striatum at intermediate time points $[F(3,21)=3.3, p<0.05]$ relative to vehicle-treated controls (Fig. 5a). Due to very low basal levels of DARPP-32 expression in the hippocampus, phosphorylation of this protein in response to SKF 83822 and SKF 83959 was not examined.

\section{Discussion}

Determining the precise functional roles of individual dopamine $\mathrm{D}_{1}$-like receptors has been complicated at two levels. Firstly, because of their close structural homology, no compounds have yet been developed which bind selectively at $\mathrm{D}_{1}$ vs $\mathrm{D}_{5}$ receptors (Waddington et al., 2005). Secondly, multiple intracellular signal transduction coupling at each receptor serves to increase their functional diversity (O'Sullivan et al., 2004). The availability and detailed characterisation of $D_{1}$ and $D_{5}$ receptor knockouts has increased our understanding of the gross functional roles of these receptors (Clifford et al., 1998, 1999; McNamara et al., 2003; O'Sullivan et al., 2005; Waddington et al., 2005); however, detailed information on the functional correlates of heterogeneous intracellular signalling at individual $\mathrm{D}^{- \text {-like receptors }}$ is needed. The present phenotypic characterisation of the AC-stimulating $\mathrm{D}_{1}$-like agonist SKF 83822 in $\mathrm{D}_{1}$ knockout mice addresses this issue by allowing systematic comparison with previous studies in our laboratory examining the behavioral effects of the PLCstimulating agonist SKF 83959 in such mutants (McNamara et al., 2003) and both compounds in $\mathrm{D}_{5}$ knockout mice (O'Sullivan et al., 2005).

Homozygous $\mathrm{D}_{1}$ knockouts are unresponsive to the behavioral effects of SKF 83822 as indicated by its failure to alter vehicle-treated levels for all topographies of behavior. Nonresponse of $D_{1}$ knockouts to doses of SKF 83822 producing profound phenotypic effects in wild-types suggests that, within the $\mathrm{D}_{1}$-like subfamily, stimulation of $\mathrm{D}_{1}$ receptors coupled to $\mathrm{AC}$ is a fundamental requirement for the actions of this drug. The present finding supports our recent observation that behavioral responsiveness to SKF 83822 is essentially conserved in homozygous $\mathrm{D}_{5}$ knockouts, with only a modest increase in a discrete topography of exploratory rearing encountered (O'Sullivan et al., 2005). As expected, SKF 83822 did not readily induce grooming, particularly syntactic intense grooming behavior in either wildtypes or $\mathrm{D}_{1}$ knockouts (O'Sullivan et al., 2005, 2006). A significant dose $\times$ genotype interaction for overall levels of grooming at higher doses most likely reflects moderate inhibition of grooming in control animals with the emergence of prominent seizures, rather than a dose-dependent release of this behavior in $\mathrm{D}_{1}$ knockouts per se. Failure of SKF 83822 to induce syntactic intense grooming in a manner characteristic of other selective $\mathrm{D}_{1}$-like agonists (Waddington et al., 1995), combined with previous reports that the ability of SKF 83959 to stimulate intense grooming is reduced in both congenic $D_{1}$ and $D_{5}$ knockouts (McNamara et al., 2003; O'Sullivan et al., 2005), provides additional evidence that $\mathrm{D}_{1}$-like receptor coupling to PLC (but not AC) is necessary to induce complex syntactic grooming behavior, possibly via heterooligomerisation with $\mathrm{D}_{2}$ receptors (O'Sullivan et al., 2004; Rashid et al., 2007).

A major finding of the present study is that the characteristic induction of behavioral seizures following challenge with SKF 83822 is abolished in mice with homozygous deletion of the $\mathrm{D}_{1}$ receptor. This finding supports our recent observation that SKF 83822induced behavioral seizures are conserved in $\mathrm{D}_{5}$ receptor knockouts (O'Sullivan et al., 2005) and, together with numerous reports that the PLC-stimulating SKF 83959 does not induce seizures (Clifford et al., 1999; McNamara et al., 2003; O'Sullivan et al., 2005, 2006), provides strong evidence that the ability of certain $\mathrm{D}_{1}$-like agonists to lower seizure threshold (DeNinno et al., 1991; Starr and Starr, 1993) is critically dependent on selective 
$\mathrm{D}_{1}$ receptor stimulation of $\mathrm{AC}$-mediated signalling transduction cascades. Unlike other selective $\mathrm{D}_{1}$-like agonists, SKF 83822 induced mildly stereotyped sniffing, locomotion and rearing directed around the perimeter of the cage (thigmotaxis) in wild-type but not $\mathrm{D}_{1}$ knockouts. This atypical $\mathrm{D}_{1}$-like dependent pattern of behavior coincided with the emergence of seizures, was most prominent inter-ictally and was observed in $\mathrm{D}_{5}$ and DARPP-32 knockouts evidencing seizures. Thus, atypical stereotypy in response to SKF 83822 may represent idiosyncratic post-ictal behavioral stimulation.

To confirm and elaborate the mechanisms of seizure generation at $\mathrm{D}_{1}$-like receptors coupled to AC, cortical EEG recording was used to examine the seizure profile of SKF 83822 in $\mathrm{D}_{1}$, $\mathrm{D}_{5}$ and DARPP-32 knockouts. Despite the use of congenic mutants throughout, differences in the overall number of drug-induced seizures were recorded between wild-types for each knockout line. The inherent variability of seizure generation and/or subtle genetic heterogeneity between the commercially available inbred C57BL/6 strains used to backcross the original hybrid lines in establishing congenicity may have produced this effect (McKhann et al., 2003; Mohajeri et al., 2004). Regardless, within each knockout line, clear genotypic differences and a consistent pattern of EEG seizure typology in wild-types were apparent. In agreement with our behavioral observations, all SKF 83822-induced EEG seizure events (see Materials and Methods) were abolished in homozygous $\mathrm{D}_{1}$ knockouts. Interestingly, the ability of SKF 83822 to lower seizure threshold was strongly attenuated in heterozygous $\mathrm{D}_{1}$ mutants, indicating that gene dosage is integral to the mechanism of seizure generation at $\mathrm{D}_{1}$ receptors. Unlike homozygous $\mathrm{D}_{1}$ knockouts, the majority of homozygous $\mathrm{D}_{5}$ knockouts did evidence type IV EEG seizures; however, the latency to first seizure was significantly increased in these mutants. Furthermore, the overall number of EEG seizures (type II-IV; see Materials and Methods) were reduced similarly in both heterozygous and homozygous $\mathrm{D}_{5}$ knockouts, indicating that decreasing the level of $\mathrm{D}_{5}$ receptor expression beyond 50\% cannot further attenuate seizure responses to SKF 83822 . When compared with our previous observation that SKF 83822-induced behavioral seizures are conserved in $\mathrm{D}_{5}$ knockouts (O'Sullivan et al., 2005), the present findings using EEG which is a more sensitive detector of seizure activity than behavioral assessment alone indicate that loss of $\mathrm{D}_{5}$ receptors is associated with a substantive but only partial reduction in seizure episodes, with those remaining being relatively enriched in type III/IV EEG events. Collectively, these EEG findings reveal a modest functional role for the $\mathrm{D}_{5}$ receptor in mediating the convulsant effects of SKF 83822 that could not be determined using behavioral assessment alone. Given that a limited number of $\mathrm{D}_{5}$ knockouts were available to generate the results reported here, more comprehensive EEG studies using SKF 83822 in these mutants are needed to clarify further the precise involvement of $\mathrm{D}_{5}$ receptors, relative to $D_{1}$ receptors, in lowing seizure threshold via $D_{1}$-like receptors. A modest role for $D_{5}$ receptors in the mechanisms of seizure generation by selective $\mathrm{D}_{1}$-like agonists might be expected given the well established preponderance of $\mathrm{D} 1$ vs $\mathrm{D}_{5}$ receptor expression in both striatal and cortical brain regions.

It is well established that DARPP-32 is an important integrator of signal transduction pathways involving cAMP-dependent activation of PKA in dopaminoceptive neurons (Svenningsson et al., 2004, 2005). It was therefore of interest to examine the effects of SKF 83822 in mice lacking functional DARPP-32. Notably, SKF 83822 was without effect in the majority of DARPP-32 knockouts tested, consistent with a major role for DARPP-32 in the mechanisms of seizure generation at $\mathrm{D}_{1}$-like receptors; of those which did evidence seizures, there was a prolonged latency to first seizure and reductions in the overall number of seizures and type IV EEG events. As discussed in relation to $\mathrm{D}_{5}$ receptors, more comprehensive EEG studies using SKF 83822 in DARPP-32 knockouts are needed to clarify further the precise involvement of DARPP-32 in lowing seizure threshold via $\mathrm{D}_{1}$-like receptors. In order to verify that SKF 83822 does indeed modulate the activity of 
DARPP-32, immunoblotting was performed to detect the level of DARPP-32 phosphorylation at Thr34 in whole striatum at various time points following systemic administration of the convulsive dose of SKF 83822 used for EEG studies. Unexpectedly, SKF 83822-induced DARPP-32 phosphorylation varied dramatically between animals at each time point. Such variability may be related to the seizure status of a given animal at the time of phosphoprotein determination, whereby DARPP-32 phosphorylation is elevated in advance of and during EEG seizures and inhibited during episodes of post-ictal EEG depression. In support of this hypothesis, a robust five-fold increase in SKF 83822-induced DARPP-32 phosphorylation at Thr34 was observed in striatal slices, which are insensitive to the effects produced by seizure activity in distal brain regions connected to the striatum. Interestingly, the PLC-stimulating agonist SKF 83959 was found to inhibit DARPP-32 phosphorylation at Thr34 in the striatum, which may explain its lack of convulsant effect. Of note, Rashid and colleagues (2007) have recently reported that SKF 83959 stimulates PLC and intracellular calcium release by activating $\mathrm{D}_{1}-\mathrm{D}_{2}$ heterooligomers where it is a full agonist at the $\mathrm{D}_{1}$ receptor and a partial agonist at the $\mathrm{D}_{2}$ receptor; $\mathrm{D}_{2}$ receptor activation inhibits DARPP-32 phosphorylation at Thr34 and is known to be anticonvulsant (Bozzi et al., 2000; Svenningsson et al., 2004, 2005).

In this study, we show that the AC-stimulating agonist SKF 83822, but not the PLCstimulating agonist SKF 83959, induces prominent ERK1/2 phosphorylation in both the hippocampus and striatum, suggesting that seizure induction at $\mathrm{D}_{1}$-like receptors involves AC-dependent activation of ERK1/2 signalling. ERK1/2 are implicated in the modulation of dendritic potassium channels in the hippocampus (Watanabe et al., 2002; Yuan et al., 2002). In particular, ERK-dependent phosphorylation of the Kv4.2 potassium channel subunit has been shown to reduce A-type currents and increase excitability of CA1 pyramidal neurons, an effect that could be involved in epileptiform activity (Francis et al., 1997). It has recently been reported that ERK signalling at $\mathrm{D}_{1}$ receptors occurs via an AC/PKA/DARPP-32 pathway, as the ability of amphetamine to induce ERK activation is absent in DARPP-32 mutants (Valjent et al., 2005). It is unclear if a similar mechanism is responsible for ERK1/2 activation in the present study; however, the fact that SKF 83822-induced seizures were observed in a small number of DARPP-32 knockouts suggests that additional signalling pathways exist which permit ERK1/2 activation in response to seizure-producing stimulation of $\mathrm{D}_{1}$-like receptors. In this regard, $\mathrm{D}_{1}$ receptor stimulation has been shown to facilitate glutamatergic synaptic transmission through the modulation of $N$-methyl- $D$ aspartate and AMPA receptor function (Levine et al., 1996; Cepeda et al., 1998; Snyder et al., 2000; Mangiavacchi and Wolf, 2004) which can, in turn, activate ERK1/2 in a DARPP-32-independent manner (Valjent et al., 2005; Girault et al., 2007). Our finding that SKF 83822, but not SKF 83959, induces prominent phosphorylation of the AMPA receptor subunit GluR1 at Serine 845 suggests that similar processes might be responsible, at least in part, for the increase in ERK1/2 phosphorylation observed here. Given that ERK1/2 activation has recently been observed in response to seizure-producing stimuli at nondopamine receptors (Merlo et al., 2004), it is plausible that ERK1/2 function as coincident detectors of generalised epileptiform activity. Although targeted deletion of the ERK2 gene is lethal in utero (Yao et al., 2003; Saba-El-Leil et al., 2003), future studies examining the seizure profile of diverse chemoconvulsants, including SKF 83822, in ERK1 knockouts (Pages et al., 1999) or in combination with SL327 (an upstream inhibitor of ERK) may reveal novel strategies for seizure prevention. Given the present effects of SKF 83822 on the phosphorylation of DARPP-32, ERK1/2 and GluR1-AMPA receptor subunits in wild-type mice, a priority for future experiments will be to test the hypothesis that phosphorylation of these proteins is reduced in $\mathrm{D}_{1} / \mathrm{D}_{5}$ receptor and DARPP-32 knockouts receiving a convulsant dose of SKF 83822. Additionally, characterising the effects of SKF 83822 in other brain regions related to seizures such as the cerebral cortex and on the phosphorylation 
and expression of individual GABA receptor subtypes will be important in elucidating further the precise dopaminergic mechanisms involved in seizure generation.

In conclusion, the present findings, together with previous studies in our laboratory (McNamara et al., 2003; O'Sullivan et al., 2005), confirm that discrete elements of $\mathrm{D}_{1}$ receptor function involve exclusive coupling to $\mathrm{AC}$, while others are mediated by coupling to PLC. We have shown that the ability of $\mathrm{D}_{1}$-like receptor stimulation to lower seizure threshold involves DARPP-32 and perhaps ERK1/2 activation, possibly via functional interaction with glutamatergic signalling. Given well-described species differences in response to centrally acting dopamine agonists, the clinical implications of the pre-clinical findings reported here remain to be clarified. Regardless, considering the need for improved therapeutic strategies in epilepsy, further research evaluating the role of $\mathrm{D}_{1}$ receptor signalling in seizure processes is warranted.

\section{Acknowledgments}

These studies were supported by: Science Foundation Ireland; the Irish Research Council for Science, Engineering and Technology (IRCSET); Swedish Research Council grants 13482 and 14862; NIH grants MH074866 and DA10044; USAMRAA grants DAMD17-02-1-0705 and W81XWH-05-1-0146. SKF 83959 was provided by RBI and subsequently SRI as part of the Chemical Synthesis Program of the National Institutes of Mental Health. JD is a National Health \& Medical Research Council Practitioner Fellow.

\section{References}

Bozzi Y, Vallone D, Borrelli E. Neuroprotective role of dopamine against hippocampal cell death. Journal of Neuroscience. 2000; 20:8643-8649. [PubMed: 11069974]

Cepeda C, Colwell CS, Itri JN, Gruen E, Levine MS. Dopaminergic modulation of early signs of excitotoxicity in visualized rat neostriatal neurons. European Journal of Neuroscience. 1998; 10:3491-3497. [PubMed: 9824462]

Chen J, Rusnak M, Luedtke RR, Sidhu A. D1 dopamine receptor mediates dopamine-induced cytotoxicity via the ERK signal cascade. Journal of Biological Chemistry. 2004; 279:39317-39330. [PubMed: 15247297]

Clifford JJ, Tighe O, Croke DT, Sibley DR, Drago J, Waddington JL. Topographical evaluation of the phenotype of spontaneous behaviour in mice with targeted gene deletion of the D1A dopamine receptor: paradoxical elevation of grooming syntax. Neuropharmacology. 1998; 37:1595-1602. [PubMed: 9886682]

Clifford JJ, Tighe O, Croke DT, Kinsella A, Sibley DR, Drago J, Waddington JL. Conservation of behavioural topography to dopamine D1-like receptor agonists in mutant mice lacking the D1A receptor implicates a D1-like receptor not coupled to adenylyl cyclase. Neuroscience. 1999; 93:1483-1489. [PubMed: 10501473]

DeNinno MP, Schoenleber R, MacKenzie R, Britton DR, Asin KE, Briggs C, Trugman JM, Ackerman M, Artman L, Bednarz L, Bhatt R, Curzon P, Gomez E, Kang CH, Stittsworth J, Kebabian JW. A68930: a potent agonist selective for the dopamine D1 receptor. European Journal of Pharmacology. 1991; 199:209-219. [PubMed: 1683288]

Drago J, Gerfen CR, Lachowicz JE, Steiner H, Hollon TR, Love PE, Ooi GT, Grinberg A, Lee EJ, Huang SP, Bartlett PF, Jose PA, Sibley DR, Westphal H. Altered striatal function in a mutant mouse lacking D1A dopamine receptors. Proceeding of the National Academy of Sciences USA. 1994; 91:12564-12568.

Ferraro TN, Golden GT, Smith GG, St Jean P, Schork NJ, Mulholland N, Ballas C, Schill J, Buono RJ, Berrettini WH. Mapping loci for pentylenetetrazol-induced seizure susceptibility in mice. Journal of Neuroscience. 1999; 19:6733-6739. [PubMed: 10436030]

Fienberg AA, Hiroi N, Mermelstein PG, Song W, Snyder GL, Nishi A, Cheramy A, O'Callaghan JP, Miller DB, Cole DG, Corbett R, Haile CN, Cooper DC, Onn SP, Grace AA, Ouimet CC, White FJ, Hyman SE, Surmeier DJ, Girault J, Nestler EJ, Greengard P. DARPP-32: regulator of the efficacy of dopaminergic neurotransmission. Science. 1998; 281:838-842. [PubMed: 9694658] 
Francis J, Jugloff DG, Mingo NS, Wallace MC, Jones OT, Burnham WM, Eubanks JH. Kainic acidinduced generalized seizures alter the regional hippocampal expression of the rat Kv4.2 potassium channel gene. Neuroscience Letters. 1997; 232:91-4. [PubMed: 9302094]

Girault JA, Valjent E, Caboche J, Herve D. ERK2: a logical AND gate critical for drug-induced plasticity? Current Opinion in Pharmacology. 2007; 7:77-85. [PubMed: 17085074]

Hakansson K, Galdi S, Hendrick J, Snyder G, Greengard P, Fisone G. Regulation of phosphorylation of the GluR1 AMPA receptor by dopamine D2 receptors. Journal of Neurochemistry. 2006; 96:482-488. [PubMed: 16336634]

Hemmings HC, Greengard P. DARPP-32, a dopamine- and adenosine $3^{\prime}: 5^{\prime}$-monophosphate-regulated phosphoprotein: regional, tissue, and phylogenetic distribution. Journal of Neuroscience. 1986; 6:1469-81. [PubMed: 3711991]

Hollon TR, Bek MJ, Lachowicz JE, Ariano MA, Mezey E, Ramachandran R, Wersinger SR, Soaresda-Silva P, Liu ZF, Grinberg A, Drago J, Young WS 3rd, Westphal H, Jose PA, Sibley DR. Mice lacking D5 dopamine receptors have increased sympathetic tone and are hypertensive. Journal of Neuroscience. 2002; 22:10801-10810. [PubMed: 12486173]

Holmes A, Hollon TR, Gleason TC, Liu Z, Dreiling J, Sibley DR, Crawley JN. Behavioral characterization of dopamine D5 receptor null mutant mice. Behavioral Neuroscience. 2001; 115:1129-1144. [PubMed: 11584926]

Jin LQ, Goswami S, Cai G, Zhen X, Friedman E. SKF83959 selectively regulates phosphatidylinositol-linked D1 dopamine receptors in rat brain. Journal of Neurochemistry. 2003; 85:378-386. [PubMed: 12675914]

Levine MS, Altemus KL, Cepeda C, Cromwell HC, Crawford C, Ariano MA, Drago J, Sibley DR, Westphal H. Modulatory actions of dopamine on NMDA receptor-mediated responses are reduced in D1A-deficient mutant mice. Journal of Neuroscience. 1996; 16:5870-5882. [PubMed: 8795639]

Mangiavacchi S, Wolf ME. D1 dopamine receptor stimulation increases the rate of AMPA receptor insertion onto the surface of cultured nucleus accumbens neurons through a pathway dependent on protein kinase A. Journal of Neurochemistry. 2004; 88:1261-1271. [PubMed: 15009682]

McKhann GM 2nd, Wenzel HJ, Robbins CA, Sosunov AA, Schwartzkroin PA. Mouse strain differences in kainic acid sensitivity, seizure behavior, mortality, and hippocampal pathology. Neuroscience. 2003; 122:551-561. [PubMed: 14614919]

McNamara FN, Clifford JJ, Tighe O, Kinsella A, Drago J, Croke DT, Waddington JL. Congenic D1A dopamine receptor mutants: ethologically based resolution of behavioural topography indicates genetic background as a determinant of knockout phenotype. Neuropsychopharmacology. 2003; 28:86-99. [PubMed: 12496944]

Merlo D, Cifelli P, Cicconi S, Tancredi V, Avoli M. 4-Aminopyridine-induced epileptogenesis depends on activation of mitogen-activated protein kinase ERK. Journal of Neurochemistry. 2004; 89:654-659. [PubMed: 15086522]

Mohajeri MH, Madani R, Saini K, Lipp HP, Nitsch RM, Wolfer DP. The impact of genetic background on neurodegeneration and behavior in seizured mice. Genes, Brain and Behavior. 2004; 3:228-239.

Nally RE, Kinsella A, Tighe O, Croke DT, Fienberg AA, Greengard P, Waddington JL. Ethologically based resolution of D2-like dopamine receptor agonist-versus antagonist-induced behavioral topography in dopamine- and adenosine $3^{\prime}, 5^{\prime}$-monophosphate-regulated phosphoprotein of $32 \mathrm{kDa}$ 'knockout' mutants congenic on the C57BL/6 genetic background. Jornal of Pharmacology and Experimental Therapeutics. 2004; 310:1281-1287.

O’Sullivan GJ, Roth BL, Kinsella A, Waddington JL. SK\&F 83822 distinguishes adenylyl cyclase from phospholipase C-coupled dopamine D1-like receptors: behavioural topography. European Journal of Pharmacology. 2004; 486:273-280. [PubMed: 14985049]

O'Sullivan GJ, Kinsella A, Sibley DR, Tighe O, Croke DT, Waddington JL. Ethological resolution of behavioural topography and D1-like versus D2-like agonist responses in congenic D5 dopamine receptor mutants: identification of D5:D2-like interactions. Synapse. 2005; 55:201-211. [PubMed: 15668951]

O’Sullivan GJ, Kinsella A, Grandy DK, Tighe O, Croke DT, Waddington JL. Ethological resolution of behavioral topography and D2-like vs. D1-like agonist responses in congenic D4 dopamine 
receptor 'knockouts': identification of D4:D1-like interactions. Synapse. 2006; 59:107-118. [PubMed: 16320306]

O’Tuathaigh CM, O'Sullivan GJ, Kinsella A, Harvey RP, Tighe O, Croke DT, Waddington JL. Sexually dimorphic changes in the exploratory and habituation profiles of heterozygous neuregulin-1 knockout mice. Neuroreport. 2006; 17:79-83. [PubMed: 16361955]

Pages G, Guerin S, Grall D, Bonino F, Smith A, Anjuere F, Auberger P, Pouyssegur J. Defective thymocyte maturation in p44 MAP kinase (Erk 1) knockout mice. Science. 1999; 286:1374-1377. [PubMed: 10558995]

Panchalingam S, Undie AS. SKF83959 exhibits biochemical agonism by stimulating [(35)S]GTP gamma $\mathrm{S}$ binding and phosphoinositide hydrolysis in rat and monkey brain. Neuropharmacology. 2001; 40:826-837. [PubMed: 11369036]

Peacock L, Gerlach J. Aberrant behavioral effects of a dopamine D1 receptor antagonist and agonist in monkeys: evidence of uncharted dopamine D1 receptor actions. Biological Psychiatry. 2001; 50:501-9. [PubMed: 11600103]

Rashid AJ, So CH, Kong MM, Furtak T, El-Ghundi M, Cheng R, O’Dowd BF, George SR. D1-D2 dopamine receptor heterooligomers with unique pharmacology are coupled to rapid activation of Gq/11 in the striatum. Proceedings of the National Academy of Sciences USA. 2007; 104:654659.

Saba-El-Leil MK, Vella FD, Vernay B, Voisin L, Chen L, Labrecque N, Ang SL, Meloche S. An essential function of the mitogen-activated protein kinase Erk2 in mouse trophoblast development. EMBO Report. 2003; 4:964-968.

Shinoda S, Araki T, Lan JQ, Schindler CK, Simon RP, Taki W, Henshall DC. Development of a model of seizure-induced hippocampal injury with features of programmed cell death in the BALB/c mouse. Journal of Neuroscience Research. 2004; 76:121-128. [PubMed: 15048936]

Snyder GL, Girault JA, Chen JY, Czernik AJ, Kebabian JW, Nathanson JA, Greengard P. Phosphorylation of DARPP-32 and protein phosphatase inhibitor-1 in rat choroid plexus: regulation by factors other than dopamine. Journal of Neuroscience. 1992; 12:3071-3083. [PubMed: 1494946]

Snyder GL, Allen PB, Fienberg AA, Valle CG, Huganir RL, Nairn AC, Greengard P. Regulation of phosphorylation of the GluR1 AMPA receptor in the neostriatum by dopamine and psychostimulants in vivo. Journal of Neuroscience. 2000; 20:4480-4488. [PubMed: 10844017]

Starr MS. The role of dopamine in epilepsy. Synapse. 1996; 22:159-194. [PubMed: 8787131]

Starr MS, Starr BS. Seizure promotion by D1 agonists does not correlate with other dopaminergic properties. Journal of Neural Transmission Parkinson's Disease and Dementia Section. 1993; 6:27-34.

Svenningsson P, Lindskog M, Ledent C, Parmentier M, Greengard P, Fredholm BB, Fisone G. Regulation of the phosphorylation of the dopamine- and cAMP-regulated phosphoprotein of 32 $\mathrm{kDa}$ in vivo by dopamine D1, dopamine D2, and adenosine A2A receptors. Proceedings of the National Academy of Sciences USA. 2000; 97:1856-1860.

Svenningsson P, Nishi A, Fisone G, Girault JA, Nairn AC, Greengard P. DARPP-32: an integrator of neurotransmission. Annual Review of Pharmacology and Toxicology. 2004; 44:269-296.

Svenningsson P, Nairn AC, Greengard P. DARPP-32 mediates the actions of multiple drugs of abuse. The AAPS Journal. 2005; 7:353-360.

Thomas GM, Huganir RL. MAPK cascade signalling and synaptic plasticity. Nature Reviews Neuroscience. 2004; 5:173-183.

Towbin H, Staehelin T, Gordon J. Electrophoretic transfer of proteins from polyacrylamide gels to nitrocellulose sheets: procedure and some applications. Proceedings of the National Academy of Sciences USA. 1979; 76:4350-4354.

Undie AS, Weinstock J, Sarau HM, Friedman E. Evidence for a distinct D1-like dopamine receptor that couples to activation of phosphoinositide metabolism in brain. Journal of Neurochemistry. 1994; 62:2045-2048. [PubMed: 7908949]

Valjent E, Corvol JC, Pages C, Besson MJ, Maldonado R, Caboche J. Involvement of the extracellular signal-regulated kinase cascade for cocaine-rewarding properties. Journal of Neuroscience. 2000; 20:8701-8709. [PubMed: 11102476] 
Valjent E, Pascoli V, Svenningsson P, Paul S, Enslen H, Corvol JC, Stipanovich A, Caboche J, Lombroso PJ, Nairn AC, Greengard P, Herve D, Girault JA. Regulation of a protein phosphatase cascade allows convergent dopamine and glutamate signals to activate ERK in the striatum. Proceedings of the National Academy of Sciences USA. 2005; 102:491-496.

Waddington JL, Daly SA, Downes RP, Deveney AM, McCauley PG, O'Boyle KM. Behavioural pharmacology of 'D1-like' dopamine receptors: further subtyping, new pharmacological probes and interactions with 'D2-like' receptors. Progress in Neuropsychopharmacology and Biological Psychiatry. 1995; 19:811-831.

Waddington JL, O'Tuathaigh C, O’Sullivan G, Tomiyama K, Koshikawa N, Croke DT. Phenotypic studies on dopamine receptor subtype and associated signal transduction mutants: insights and challenges from 10 years at the psychopharmacology-molecular biology interface.

Psychopharmacology. 2005; 181:611-638. [PubMed: 16041535]

Watanabe S, Hoffman DA, Migliore M, Johnston D. Dendritic K+ channels contribute to spike-timing dependent long-term potentiation in hippocampal pyramidal neurons. Proceedings of the National Academy of Sciences USA. 2002; 99:8366-71.

Weinshenker D, Szot P. The role of catecholamines in seizure susceptibility: new results using genetically engineered mice. Pharmacology and Therapeutics. 2002; 94:213-233. [PubMed: 12113799]

Yao Y, Li W, Wu J, Germann UA, Su MS, Kuida K, Boucher DM. Extracellular signal-regulated kinase 2 is necessary for mesoderm differentiation. Proceedings of the National Academy of Sciences USA. 2003; 100:12759-12764.

Yuan LL, Adams JP, Swank M, Sweatt JD, Johnston D. Protein kinase modulation of dendritic K+ channels in hippocampus involves a mitogen-activated protein kinase pathway. Journal of Neuroscience. 2002; 22:4860-8. [PubMed: 12077183] 

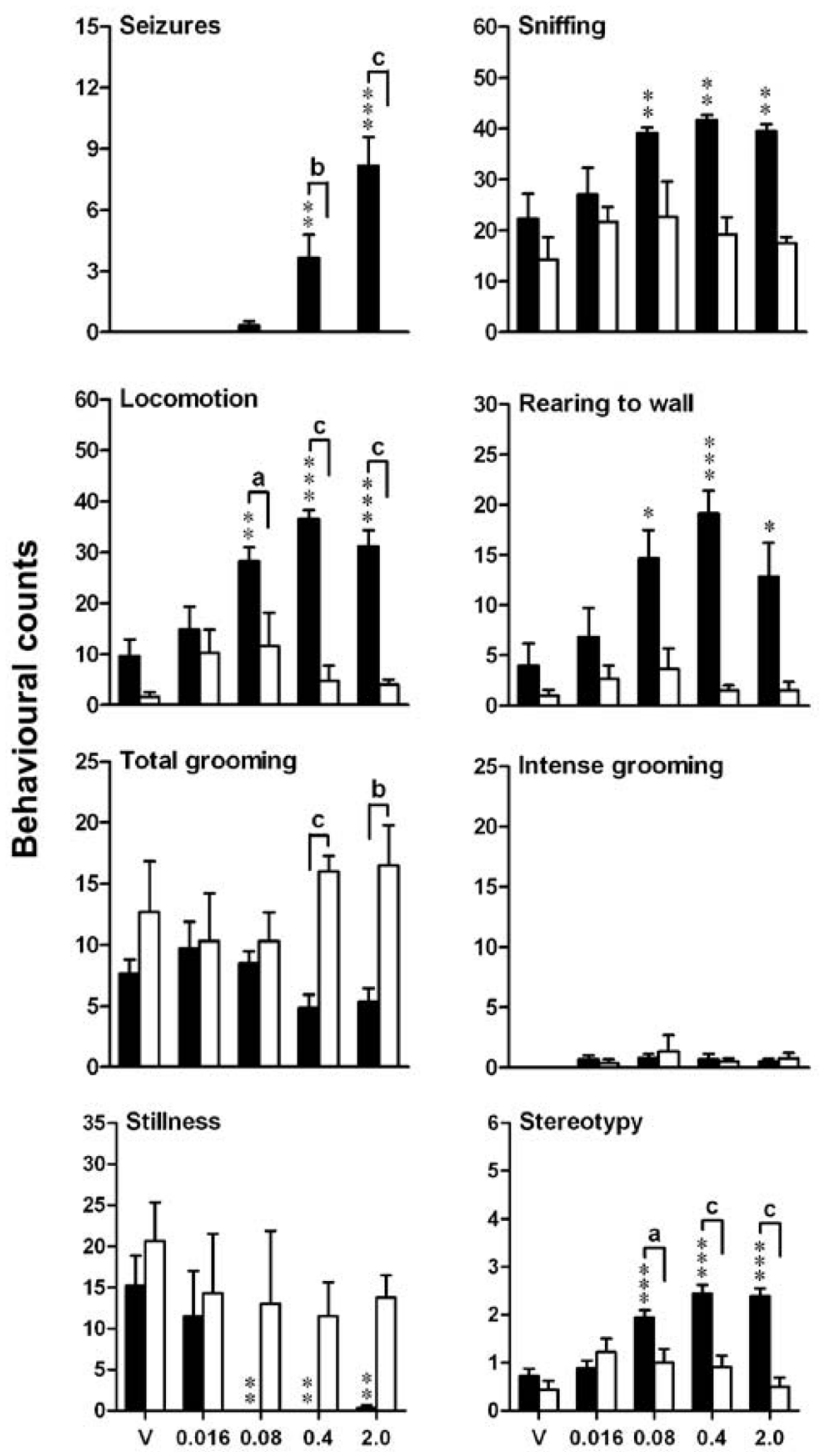

SKF $83822(\mathrm{mg} / \mathrm{kg})$

Fig. 1.

Behavioral phenotype in response to SKF $83822(0.016-2.0 \mathrm{mg} / \mathrm{kg}$ s.c.) or vehicle (V) following $3 \mathrm{~h}$ of habituation. Data are mean behavioral counts \pm SEM over a 60 min period for seizures, sniffing, locomotion, rearing to wall, total grooming, intense grooming and stillness, with stereotypy scores, for wild-type ( $n=6$ females, filled columns) and homozygous $\mathrm{D}_{1}$ knockout ( $n=3-4$ females, open columns) mice. ${ }^{*} p<0.05$, $* * p<0.01$, $* * * p<0.001$ vs vehicle-treated wild-type controls. ${ }^{\mathrm{a}} p<0.05,{ }^{\mathrm{b}} p<0.01,{ }^{\mathrm{c}} p<0.001$ between genotypes receiving the same dose. 


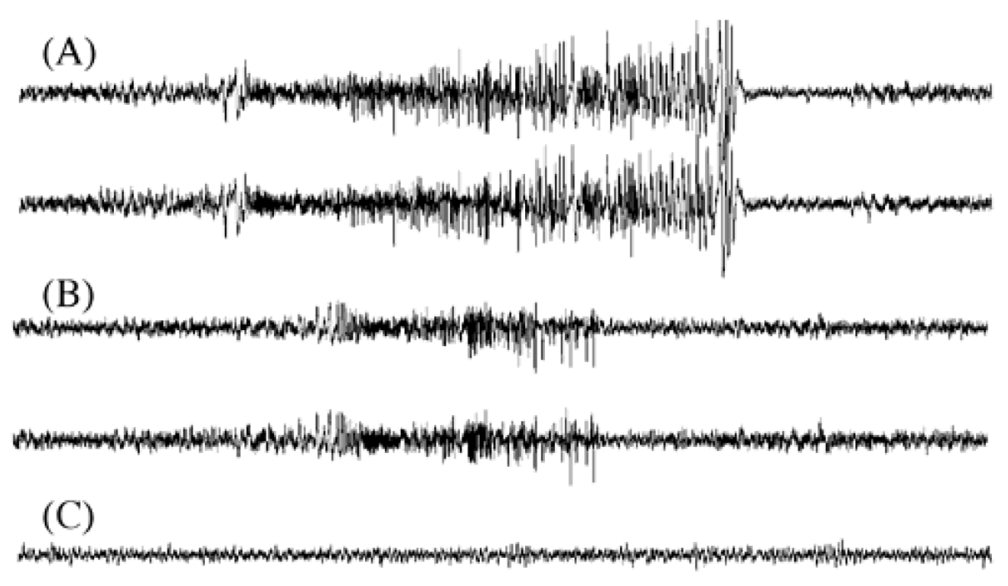

Fig. 2.

Representative EEGs following challenge with SKF 83822 (2.0 mg/kg s.c.). All traces were captured during the convulsive phase of the drug (20-60 min post-SKF 83822 injection). (a) $\mathrm{D}_{1}$ wild-type mouse demonstrating a type IV EEG seizure (high frequency, high voltage spiking), corresponding to a phase 4 behavioral seizure (tonic-clonic seizure or rapid jumping and wild running). (b) Heterozygous $\mathrm{D}_{1}$ knockout mouse demonstrating a type II EEG seizure (high frequency [>1 Hz], low voltage spiking; no behavioral correlate). (c) Homozygous $\mathrm{D}_{1}$ knockout mouse demonstrating no EEG abnormalities in response to SKF 83822. Scale bar $=4 \mathrm{~s}$. 
a)
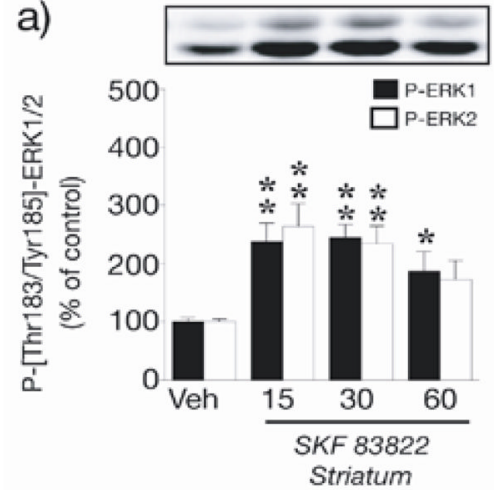

c)
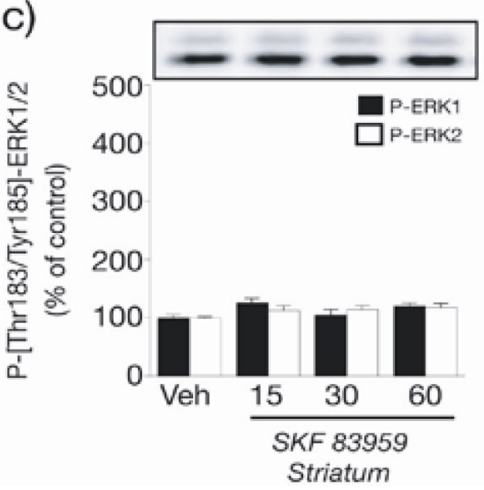

b)

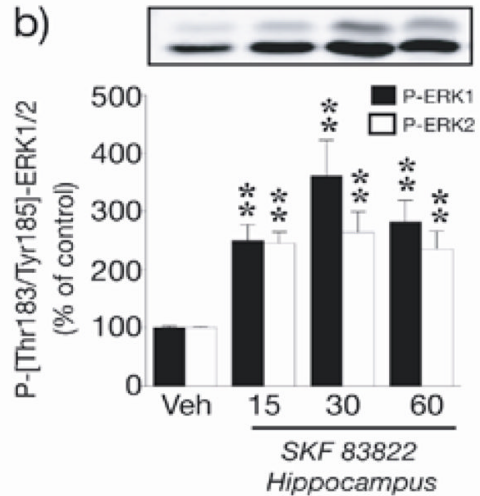

d)

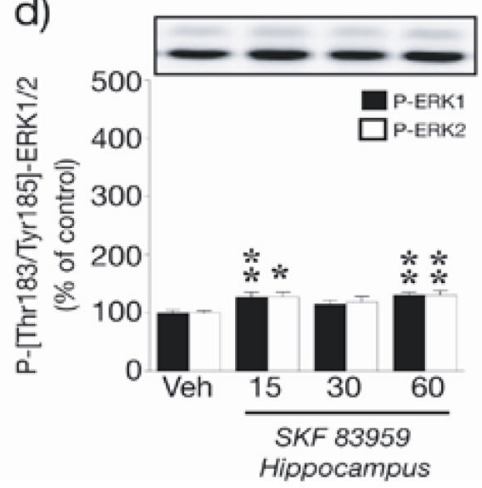

Fig. 3.

SKF 83822 and SKF 83959 exhibit distinct modulatory effects on ERK1/2 phosphorylation in the striatum and hippocampus. Wild-type C57BL/6 mice were treated with either SKF 83822 (a,b) or SKF 83959 (c,d) [both $2.0 \mathrm{mg} / \mathrm{kg}$ s.c.] and sacrificed by decapitation at various time points $(15,30$ or $60 \mathrm{~min})$. Phospho-Thr183/Tyr185-ERK1/2 was determined by Western blotting using a phosphorylation state-specific antibody. Upper panels show representative autoradiograms. Lower panels show a summary of the data expressed as means \pm SEM. $(n=5-12)$. The amount of phospho-Thr183/Tyr185-ERK1/2 is expressed as a percentage of that determined after vehicle administration. $* p<0.05, * * p<0.01 \mathrm{vs}$ vehicle-treated controls. 
a)


b)

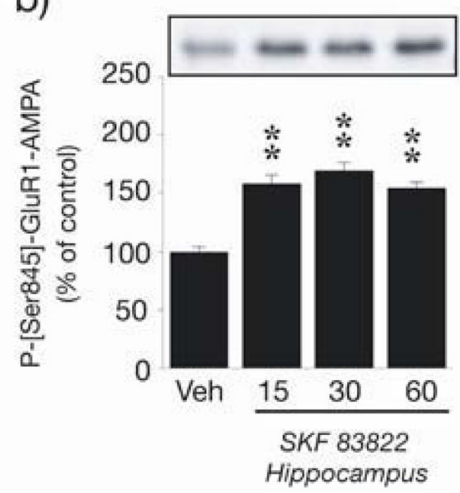

d)

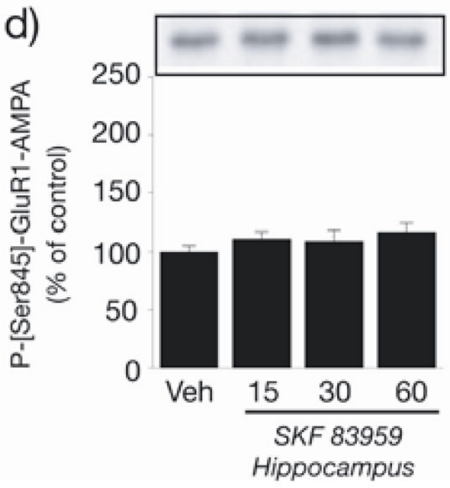

Fig. 4.

SKF 83822 and SKF 83959 both stimulate phospho-Ser845-GluR1 in the striatum, but have distinct effects on GluR1 phosphorylation in the hippocampus. Wild-type C57BL/6 mice were treated with either SKF 83822 (a,b) or SKF 83959 (c,d) [both $2.0 \mathrm{mg} / \mathrm{kg}$ s.c.] and sacrificed by decapitation at various time points $(15,30$ or $60 \mathrm{~min})$. Phosphorylation of GluR1 at Ser845 was determined by Western blotting using a polyclonal phosphorylationstate specific antibody. Upper panels show representative autoradiograms. Lower panels show a summary of the data expressed as means $\pm \operatorname{SEM}(n=6-12)$. The amount of phospho-Ser845-GluR1 is expressed as a percentage of that determined after vehicle administration. $* p<0.05, * * p<0.01$ vs vehicle-treated controls. 

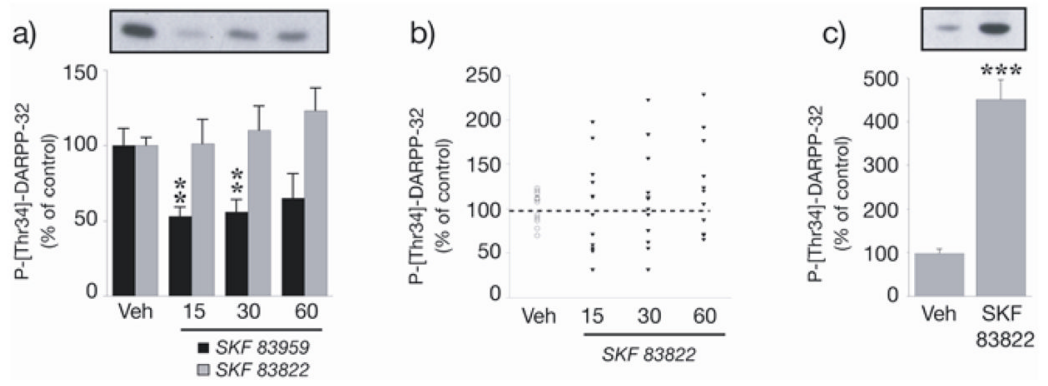

Fig. 5.

Effect of SKF 83822 and SKF 83959 on DARPP-32 phosphorylation at Thr34 in the striatum. (a) Determination of DARPP-32 phosphorylation in whole striatum. Wild-type C57BL/6 mice were treated with either SKF 83822 or SKF 83959 [both $2.0 \mathrm{mg} / \mathrm{kg}$ s.c.] and sacrificed by decapitation at various time points (15, 30 or $60 \mathrm{~min})$. Phospho-Thr34DARPP-32 was determined by Western blotting using a phosphorylation-state specific antibody. Upper panel shows a representative autoradiogram for SKF 83959. Lower panel shows a summary of the data expressed as means \pm SEM $(n=6-12)$. The amount of phosphorylated DARPP-32 is expressed as percentage of that determined after vehicle administration. $* p<0.05$ vs vehicle-treated controls. (b) Scatter plot of the experiment for SKF 83822 shown in (a). (c) Determination of DARPP-32 phosphorylation in striatal slices following $5 \mathrm{~min}$ incubation in the presence of SKF $83822(1 \mu \mathrm{M}) . * * p<0.001$ vs vehicletreated controls. 
Table 1

SKF 83822-induced EEG profile in $\mathrm{D}_{1}, \mathrm{D}_{5}$ and DARPP-32 knockouts

\begin{tabular}{|c|c|c|c|c|}
\hline Genotype & Number per group $(n)$ & Latency to $1^{\text {st }}$ seizure (min) & $\begin{array}{l}\text { Total number of EEG } \\
\text { seizures }\end{array}$ & $\begin{array}{l}\text { Number of type IV EEG } \\
\text { seizures }\end{array}$ \\
\hline $\mathrm{D}_{1} \mathrm{WT}$ & 5 & $19 \pm 2$ & $12 \pm 3$ & $9 \pm 2$ \\
\hline $\mathrm{D}_{1} \mathrm{HET}$ & 5 & $34 \pm 4^{*}$ & $2 \pm 1^{* *}$ & $1 \pm 1^{* *}$ \\
\hline $\mathrm{D}_{1} \mathrm{KO}$ & 5 & no seizures & $0 * * a$ & $0 * *$ \\
\hline $\mathrm{D}_{5} \mathrm{WT}$ & 5 & $17 \pm 2$ & $8 \pm 1$ & $5 \pm 2$ \\
\hline $\mathrm{D}_{5} \mathrm{HET}$ & 5 & $27 \pm 1 * *$ & $2 \pm 1^{* *}$ & $2 \pm 1$ \\
\hline $\mathrm{D}_{5} \mathrm{KO}$ & 5 & $\begin{array}{l}25 \pm 4(n=4) \\
\text { no seizures }(n=1)\end{array}$ & $2 \pm 1^{* *}$ & $1 \pm 1^{*}$ \\
\hline DARPP-32 WT & 5 & $21 \pm 1$ & $5 \pm 1$ & $4 \pm 1$ \\
\hline DARPP-32 KO & 5 & $\begin{array}{l}34 \pm 4^{* *}(n=2) \\
\text { no seizures }(n=3)\end{array}$ & $1 \pm 1 *$ & $1 \pm 1^{* *}$ \\
\hline
\end{tabular}

SKF $83822(2.0 \mathrm{mg} / \mathrm{kg})$ was administered subcutaneously into the flank in a volume of $4.0 \mathrm{ml} / \mathrm{kg}$ followed immediately by extradural EEG recording for $60 \mathrm{~min}$. WT = wild-type; $\mathrm{HET}=$ heterozygous knockout; $\mathrm{KO}=$ homozygous knockout .

*

* $p<0.05$ and

**

$p<0.01$ vs respective WT;

${ }^{a} p<0.01$ vs D1 HET. Type IV seizures correspond to high frequency, high voltage EEG patterns (see Fig. 2). 